presence of only three signals in the ${ }^{1} \mathrm{H}-\mathrm{NMR}$ spectrum and of six signals in the ${ }^{13} \mathrm{C}$-NMR spectrum (Table 1 ) is consistent with a molecular structure with $D_{2 h}$ symmetry

Table 1. Spectroscopic data of 4, 9, and 10. 'H-NMR $\left(\mathrm{CDCl}_{3}, 300 \mathrm{MHz}\right)$, ${ }^{13} \mathrm{C}-\mathrm{NMR}$ ( $\left.\mathrm{CDCl}_{3}, 75.47 \mathrm{MHz}\right)$, UV ( $n$-hexane).

4: 'H-NMR: $\delta=1.14-1.28(\mathrm{~m}, 18 \mathrm{H}, t \mathrm{Bu}), 2.48-3.02\left(\mathrm{~m}, 8 \mathrm{H}, \mathrm{CH}_{2}\right), 5.75-6.26$ $(\mathrm{m}, 4 \mathrm{H}$, olefin- $\mathrm{H}) ; \mathrm{UV}: \lambda_{\max }(\lg \varepsilon)=253 \mathrm{~nm}(3.83)$

9: ${ }^{1} \mathrm{H}-\mathrm{NMR}: \delta=1.16(\mathrm{~s}, 18 \mathrm{H}, t \mathrm{Bu}), 2.39,2.86\left(2 \mathrm{br} . \mathrm{s}, 4 \mathrm{H}, \mathrm{CH}_{2}\right), 5.65$ (d, $J=2.2 \mathrm{~Hz}, 2 \mathrm{H}, 1 / 8-\mathrm{H}), 6.15(\mathrm{~s}, 2 \mathrm{H}, 3 / 6-\mathrm{H}), 6.52(\mathrm{~s}, 2 \mathrm{H}, 9 / 10-\mathrm{H})$; UV: $\lambda_{\text {max }}(\lg \varepsilon)=228(3.88) \mathrm{sh}, 262(3.47) \mathrm{sh}, 327$ (4.17) sh, 344 (4.40) sh, 358 (4.52), $376(4.40), 458 \mathrm{~nm}(2.78)$

10: ${ }^{1} \mathrm{H}-\mathrm{NMR}: \delta=1.33(\mathrm{~s}, 18 \mathrm{H}, t \mathrm{Bu}), 6.84(\mathrm{~s}, 4 \mathrm{H}, 1 / 3 / 6 / 8-\mathrm{H}), 7.27(\mathrm{~s}, 4 \mathrm{H}$, $4 / 5 / 9 / 10-\mathrm{H}) ;{ }^{13} \mathrm{C}-\mathrm{NMR}: \delta=30.22\left(\mathrm{q}, \mathrm{C}\left(\mathrm{CH}_{3}\right)_{3}\right), 32.85\left(\mathrm{~s}, \mathrm{C}\left(\mathrm{CH}_{3}\right)_{3}\right), 124.90$ (d, C-1/3/6/8), 126.15 (d, C-4/5/9/10), 139.30 (s, C-3a/5a/8a/10a), 160.87 (s, C-2/7); UV: $\lambda_{\max }(\lg \varepsilon)=217(4.19), 324(4.88) \mathrm{sh}, 335(5.02), 413$ (3.51) sh, 425 (3.54) sh, 435 (3.59), 460 (3.53), 923 (1.99), 1015 (1.93) sh, 1064 (1.91) sh, $1375 \mathrm{~nm}(1.64) \mathrm{sh}$

and delocalized $\pi$-electron system. This is confirmed by the X-ray structure analysis, ${ }^{[10]}$ which reveals a planar ring system with inversion center for 10 (Fig. 1). The maximum distance of the ring- $\mathrm{C}$ atoms from the mean plane is \pm 1.5 $\mathrm{pm}$. The perimeter of the molecule, with $\mathrm{CC}$ bond lengths of about $140 \mathrm{pm}$, exhibits substantial bond equivalency, whereas the two bridges are noticeably longer (149 pm). Thus, the bridging bonds have predominantly single-bond character, as in azulene. ${ }^{[11]}$

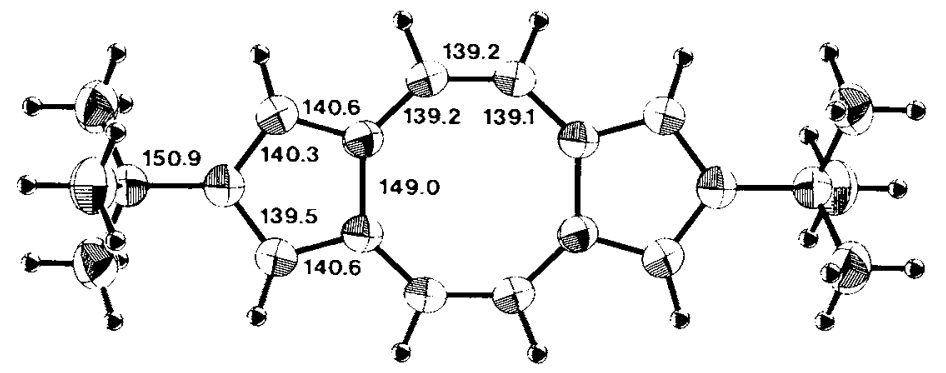

Fig. 1. Crystal structure of $\mathbf{1 0}$ (ORTEP, vibration ellipsoids at the $50 \%$ probability level) at room temperature with selected bond lengths [pm].

The analogy to azulene also extends to the electronic spectrum of 10, which like that of azulene consists of three structural band systems whose extinctions decrease with increasing wavelength. Their positions compared to those of the bands of azulene, however, are strongly bathochromically shifted, so that the longest wavelength absorptions already lie in the near IR.

10 not only belongs to the few hydrocarbons with a planar eight-membered ring, ${ }^{[1,12]}$ but, in addition, it is also a completely planar $14 \pi$-electron system which has no further cyclic conjugated subunits apart from the $14 \pi$ perimeter. The molecular structure and spectroscopic properties justify the classification of $\mathbf{1 0}$ as a non-benzenoid aromatic hydrocarbon.

Received: April 28, 1988 [Z 2727 IE] German version: Angew. Chem. 100 (1988) 1213

[1] D. Lloyd: Non-benzenoid Conjugated Carbocyclic Compounds, Elsevier, Amsterdam 1984, and references cited therein.

[2] K. Hafner, Angew. Chem. 75 (1963) 1041; Angew. Chem. Int. Ed. Engl. 3 (1964) 165; Pure Appl. Chem. Suppl. 2 (1971) 1; K. Hafner, H.-P. Krimmer, Angew. Chem. 92 (1980) 202; Angew. Chem. Int. Ed. Engl. 19 (1980) 199; K. Hafner, Pure Appl. Chem. 54 (1982) 939; K. Hafner, B. Stowas- ser, H.-P. Krimmer, S. Fischer, M. C. Böhm, H. J. Lindner, Angew. Chem. 98 (1986) 646; Angew. Chem. Int. Ed. Engl. 25 (1986) 630; E. Heilbronner, Z.-Z. Yang, ibid. 99 (1987) 369 and 26 (1987) 360; J. D. Dunitz, C. Krüger, H. Irngartinger, E. F. Maverick, Y. Wang, M. Nixdorf, ibid. 100 (1988) 415 and 27 (1988) 387

[3] A. Toyota, Bull. Chem. Soc. Jpn. 48 (1975) 1152

[4] K. Hafner, G. F. Thiele, Tetrahedron Lett. 26 (1985) 2567.

[5] All the compounds gave correct elemental analyses.

[6] R. Y. Levina, N. N. Mezentsova, O. V. Lebeda, Zh. Obshch. Khim. 29 (1955) 1079; B. F. Hallam, P. L. Pauson, J. Chem. Soc. 1958, 646; K. Alder, H.-J. Ache, F. H. Flock, Chem. Ber. 93 (1960) 1888; C. F. Wilcox, Jr., R. R. Craig, J. Am. Chem. Soc. 83 (1961) 3866; H. L. Lentzner, W. E. Watts, Tetrahedron 27 (1971) 4343.

[7] T. Kauffmann, J. Ennen, H. Lhotak, A. Rensing, F. Steinseifer, A. Woltermann, Angew. Chem. 92 (1980) 321; Angew. Chem. Int. Ed. Engl. 19 (1980) 328 .

[8] The unsubstituted 1,2-dicyclopentadienylethane can also be obtained from sodium cyclopentadienide using this method (colorless crystals, m.p. $10^{\circ} \mathrm{C}$, yield $41 \%$ ).

[9] H. Sauter, H. Prinzbach, Angew. Chem. 84 (1972) 297; Angew. Chem. Int. Ed. Engl. 11 (1972) 296; H. Sauter, B. Gallenkamp, H. Prinzbach, Chem. Ber. 110 (1977) 1382.

[10 Crystal data for 10: triclinic, $P \overline{1}, Z=1, a=955.2(4), b=866.4(4)$, $c=621.2(3) \mathrm{pm}, \alpha=105.39(1)^{\circ}, \beta=95.82(1)^{\circ}, \gamma=115.21(1)^{\circ} . \mathrm{Mo}_{\mathrm{K} \alpha}$ radiation, 1991 independent reflections, 1741 observed $(I>2 \sigma(I)), 141$ parameters refined, $R=0.062, R_{w}=0.053$. Further details of the crystal structure investigation are available on request from the Fachinformationszentrum Energie, Physik, Mathematik GmbH, D-7514 EggensteinLeopoldshafen 2 (FRG) on quoting the depository number CSD-53 098, the names of the authors, and the journal citation. We thank Prof. Dr. $H$. J. Lindner and Dr. H. Paulus for the X-ray structure analysis.

[11] K.-P. Zeller in Houben-Weyl-Müller: Methoden der organischen Chemie, Vol. $5 / 2 c$, Thieme, Stuttgart 1985 , p. 127 , and references cited therein.

[12] T. Sugimoto, M. Shibata, S. Yoneda, Z. Yoshida, Y. Kai, K. Miki, N. Kasai, T. Kobayashi, J. Am. Chem. Soc. 108 (1986) 7032; M. Oda, Pure Appl. Chem. 58 (1986) 7.

\section{Centrohexaindan, The First Hydrocarbon with Topologically Non-Planar Molecular Structure**}

\section{By Dietmar Kuck* and Andreas Schuster}

Herein we report on the synthesis of centrohexaindan 1 (hexabenzohexacyclo[5.5.2.2 $2^{4,10} \cdot 1^{1,7} \cdot 0^{4,17} \cdot 0^{10,17}$ heptadecane) and some properties of this unique hydrocarbon.

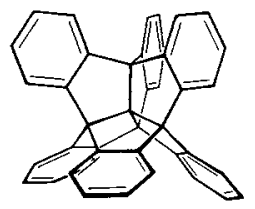

Like dodecahedrane $2^{[1,2]}$ among the spherically annelated polyquinanes, the " $\mathrm{C}_{17}$-hexaquinane"[3] 3 is the most fascinating member of the centrally annelated so-called centropolyquinanes. ${ }^{[4]}$ In contrast to 1 , however, centrohexacyclic hydrocarbons like the centrohexaquinane 3 and the corresponding hexaene 4 have not yet been synthesized, even though they are of considerable interest regarding their special ring coupling. ${ }^{[4]}$

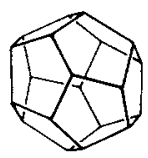

2

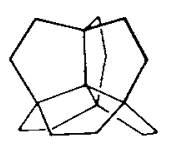

3

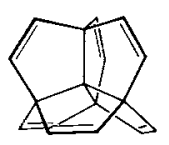

4

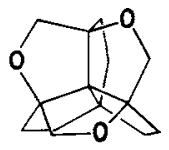

5
[*] Dr. D. Kuck, Dipl.-Chem. A. Schuster

Fakultät für Chemie der Universität

Universitātsstrasse 25, D-4800 Bielefeld 1 (FRG)

[**] Benzoannelated Centropolyquinanes, Part 5.-Part 4, see [13b] 
The only centrohexacyclic compound known so far is the triether 5, which was synthesized simultaneously by Simmons et al. ${ }^{[8]}$ and Paquette et al ${ }^{[9]}$ Attempts to prepare 3 via a route similar to that used for the synthesis of 5 have thus far failed. ${ }^{[8,9]}$ As the hexabenzo derivative of 4 , compound 1 is the first hydrocarbon with centrohexacyclic molecular structure.

The fascination of the centrohexaquinane structure of 1 lies in the annelation of six cyclopentane rings around a central $\mathrm{C}$ atom common to all rings. ${ }^{[4]}$ The central neopentane skeleton is bridged by six o-phenylene groups corresponding to the six edges of a regular tetrahedron, such that the central, quaternary $\mathrm{C}$ atom is surrounded by four further, equivalent quaternary $\mathrm{sp}^{3}-\mathrm{C}$ atoms $\mathrm{s}^{[10]}$ and therefore should exhibit ideal tetrahedral coordination. ${ }^{[1]}$ Furthermore, in the ground state 1 should have prefect $T_{\mathrm{d}}$ symmetry, in analogy to the hexaene 4 calculated by Erm$e r{ }^{[6]}$

Centrohexaindan 1 combines a number of known lower benzoannelated centropolyquinane moieties (centropolyindans). Thus, in 1 , three $2,2^{\prime}$-spirobiindans are fused along the three space axes to give a three-dimensional cross, tribenzotriquinacen $\mathrm{e}^{[12]}$ and triptindan ${ }^{[13]}$ (sym-tribenzo[3.3.3]propellane) are condensed with each other fourfold degenerate, and, finally, 1 contains three fenestranes (tetrabenzo[5.5.5.5]fenestranes, "fenestrindans") $6 .{ }^{[14]}$ It is thus the first fenestrane substituted with carbon on all four bridgeheads. ${ }^{[15]}$

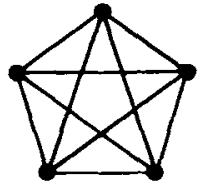

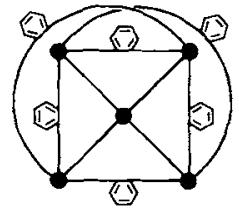

b
Fig. (. a) The graph $K_{5}$. b) A graph-theory representation of 1 .

The molecular structure of $\mathbf{1}$ is also of special interest from the point of view of the graph theory. ${ }^{[6]}$ Like the triether 5 , compound 1 is a topologically non-planar molecule. The complete mutual coupling of the five neopentane $\mathrm{C}$ atoms (vertices) via the central $\mathrm{C}-\mathrm{C}$ bonds and the peripheral $o$-phenylene bridges corresponds to the complete graphs $K_{5}$ (Fig. 1a), whose connecting lines cannot be projected into the plane without mutual intersection (Fig. ib).
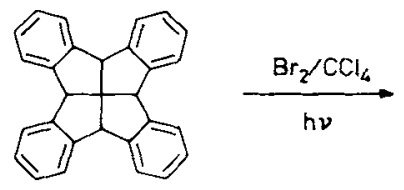

6
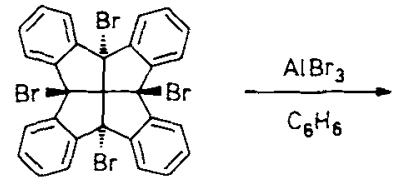

7
The synthesis of 1 , based on the recently reported fenestrindan 6, which is accessible in gram amounts in nine steps from 1,3-indandione and dibenzylideneacetone, ${ }^{[14]}$ is astonishingly easy. 6 can be readily functionalized with bromine at all four bridgeheads to give the tetrabromofenestrindan $7 .^{[16]}$ This is most surprising, since a high torsional strain should be generated by the pairwise synoriented bromine atoms on the bridgeheads. In actual fact the double 1,3-interaction in 7 leads to a conformation with $S_{4}$ symmetry which is static on the NMR time scale (Scheme 1). Therefore, different to the case of $6,{ }^{[14]}$ no $\mathrm{AA}^{\prime} \mathrm{BB}^{\prime}$ system is observed in the $300-\mathrm{MHz}{ }^{1} \mathrm{H}-\mathrm{NMR}$ spectrum for the four aromatic rings, but instead an $\mathrm{ABCX}$ system, whereby an ortho-proton is in each case strongly deshielded by the neighboring benzene ring. ${ }^{[17]}$
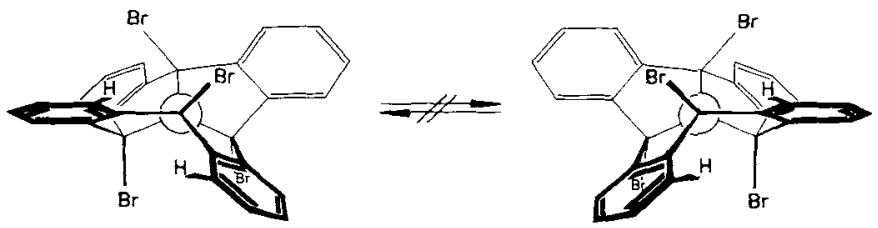

Scheme 1. Conformers of 7.

When 7 is heated together with four equivalents of $\mathrm{AlBr}_{3}$ in benzene, fourfold $\mathrm{C}-\mathrm{C}$ coupling takes place with formation of the centrohexaindan 1 in $50 \%$ overall yield! During the reaction, salt-like intermediates are formed whose structural elucidation should provide interesting details about the hitherto unknown fenestrane ions with carbenium centers at the bridgeheads.

Table 1. Spectroscopic data of centrohexaindan 1 .

MS (EI, $70 \mathrm{eV}): m / z=516\left(\mathrm{M}^{\oplus \odot}, 100 \%\right), 515(12), 439(3), 258\left(\mathrm{M}^{2 \oplus}, 4\right)$ IR (KBr): $\bar{v}=3070(\mathrm{~m}), 3020(\mathrm{~m}), 1470(\mathrm{~s}), 755,751(\mathrm{~s}), 700 \mathrm{~cm}^{-1}(\mathrm{~m})$ ${ }^{1} \mathrm{H}-\mathrm{NMR}\left(300 \mathrm{MHz}, \mathrm{CDCl}_{3}\right): \delta=7.27,7.79\left(\mathrm{AA}^{\prime} \mathrm{BB}^{\prime}\right)$

${ }^{13} \mathrm{C}-\mathrm{NMR}\left(75.8 \mathrm{MHz}, \mathrm{CD}_{2} \mathrm{Cl}_{2}\right): \delta=73.5\left(\mathrm{~s}, \mathrm{C}^{\alpha}\right), 95.4$ (s, Centro), 124.5 (d, $\left.\mathrm{C}^{\text {ortho }}\right), 129.1\left(\mathrm{~d}, \mathrm{C}^{\text {meta }}\right), 148.6\left(\mathrm{C}^{\text {ipso }}\right)$

UV (n-heptane, $\left.c=4 \cdot 10^{-5} \mathrm{~mol} \cdot \mathrm{L}^{-1}\right): \lambda_{\max }(\varepsilon)=276.5(5800), 269(4950), 263$ $(3000), 257 \mathrm{~nm}(\mathrm{~s})$

The spectroscopic data of $\mathbf{1}$ are unequivocal (Table 1). Although the solubility is quite high for a compound of this molecular size $\left(\mathrm{C}_{41} \mathrm{H}_{24}\right)$ and highly symmetrical structure compared to the lower centropolyindans, ${ }^{[12-14]}$ the melting point lies well above the usual limit $\left(420^{\circ} \mathrm{C}\right)$. As expected the mass spectrum shows no mentionable fragmentation of the molecular skeleton. The degeneracy of all six indan units of 1 manifests itself in the NMR spectra: The ' $\mathrm{H}$-NMR spectrum consists of only one $A A^{\prime} B B^{\prime}$ system for all twelve ortho and meta $\mathrm{H}$ atoms; the ${ }^{13} \mathrm{C}-\mathrm{NMR}$ spectrum shows only five signals for the total $41 \mathrm{C}$ atoms. As expected, the UV spectrum of 1 resembles those of benzoannelated centrotriquinanes and centrotetraquinanes ${ }^{[12-14]}$ and gives no indication of distinct electronic interactions between the six aromatic $\pi$ systems.

\section{Experimental}

7: $8.0 \mathrm{~mL}$ of a $1 \mathrm{M}$ solution of $\mathrm{Br}_{2}$ in $\mathrm{CCl}_{4}$ was added dropwise to a stirred suspension of $736 \mathrm{mg}(2.0 \mathrm{mmol})$ of 6 in $50 \mathrm{~mL}$ of anhydrous $\mathrm{CCl}_{4}$. After addition of $4.0 \mathrm{~mL}$ of the $\mathrm{Br}_{2} / \mathrm{CCl}_{4}$ solution a homogeneous solution formed, from which, on further addition of $\mathrm{Br}_{2} / \mathrm{CCl}_{4}$, the tetrabromide 7 precipitated. For completion of the reaction, the mixture was irradiated for ca. 20 min with a photolamp ( $500 \mathrm{~W}$ ). After removal of the solvent by evaporation and subsequent recrystallization of the lemon-yellow residue from toluene, $865 \mathrm{mg}$ of $7(63 \%)$ were obtained in the form of colorless needles (m.p. $341^{\circ} \mathrm{C}$ ).

1: A solution of $7(500 \mathrm{mg}, 0.73 \mathrm{mmol})$ in warm anhydrous benzene (100 $\mathrm{mL})$ was treated dropwise at $40^{\circ} \mathrm{C}$ within $2 \mathrm{~h}$ with $10.0 \mathrm{~mL}$ of a $0.10 \mathrm{M}$ solution of $\mathrm{AlBr}_{3}$ in benzene. An orange-red complex first separated out, and then redissolved on completion of the addition of $\mathrm{AlBr}_{3}$. The mixture was then heated under gentle reflux for $40 \mathrm{~h}$. After hydrolytic work-up and recrystallization of the light-yellow crude product from $20 \mathrm{~mL}$ of xylene, $300 \mathrm{mg}$ of $1(80 \%)$ were obtained in the form of colorless needles. 
[1] a) R. J. Ternansky, D. W. Balogh, L. A. Paquette, J. Am. Chem. Soc. 104 (1982) 4503 ; b) L. A. Paquette, R. J. Ternansky, D. W. Balogh, G. Kentgen, ibid. 105 (1983) 5446.

[2] a) W.-D. Fessner, Bulusu A. R. C. Murty, H. Prinzbach, Angew. Chem. 99 (1987) 482; Angew. Chem. Int. Ed. Engl. 26 (1987) 451; b) W.-D. Fessner, Bulusu A. R. C. Murty, J. Wörth, D. Hunkler, H. Fritz, H. Prinzbach, W. D. Roth, P. von R. Schleyer, A. B. McEwen, W. F. Maier, ibid. 99 (1987) 484 and 26 (1987) 452, resp.

[3] L. A. Paquette, R. A. Snow, J. L. Muthard, T. Cynkowski, J. Am. Chem. Soc. 100 (1978) 1600.

[4] P. Gund, T. M. Gund, J. Am. Chem. Soc. 103 (1981) 4458.

[5] O. Ermer: Aspekte von Kraftfeldrechnungen, Wolfgang-Baur-Verlag, München 1981, Chap. 4.6.3.

161 a) F. Harary in A. T. Balaban (Ed.): Chemical Applications of Graph The ory. Academic Press, London 1976, Chap. 2; b) A. T. Balaban, ibid., Chap. 3 ; c) J. Simon in R. B. King, D. H. Rouvray (Eds.): Graph Theory and Topology in Chemistry, Elsevier, Amsterdam 1987, p. 43.

[7] W. Luef, R. Keese, Helv. Chim. Acta 70 (1987) 543 .

[8] a) H. E. Simmons III, J. E. Maggio, Tetrahedron Lett. 22 (1981) 287; b) S. A. Benner, J. E. Maggio, H. E. Simmons III, J. Am. Chem. Soc. 103 (1981) 1581

[9] L. A. Paquette, M. Vazeux, Tetrahedron Lett. 22 (1981) 291.

[10] For examples of the rare central coupling of five quaternary tetracoordinated but non-equivalent $\mathrm{C}$ atoms. See: a) L. F. Pelosi, W. T. Miller, $I$. Am. Chem. Soc. 98 (1976) 4311; b) G. Maier, S. Pfriem, Angew. Chem. 90 (1978) 552; Angew. Chem. Int. Ed. Engl. I7 (1978) 520; c) J. E. Maggio, H. E. Simmons III, J. K. Kouba, J. Am. Chem. Soc. 103 (1981) 1579.

[11] For a discussion of ideal tetrahedral coordination in hydrocarbons see: a) A. Greenberg, J. F. Liebman: Strained Organic Molecules, Academic Press, New York 1978, Chap. 6; b) [7].

[12] a) D. Kuck, Angew. Chem. 96 (1984) 515; Angew. Chem. Int. Ed. Engl. 23 (1984) 508.

[13] a) D. Kuck, B. Paisdor, H.-F. Grützmacher, Chem. Ber. 120 (1987) 589; b) B. Paisdor, H.-F. Grützmacher, D. Kuck, ibid. 121 (1988) 1307.

[14] D. Kuck, H. Bögge, J. Am. Chem. Soc. 108 (1986) 8107.

[15] a) B. R. Venepalli, W. C. Agosta, Chem. Rev. 87 (1987) 399; b) K. Krohn, Nachr. Chem. Tech. Lab. 35 (1987) 264.

[16] 1 and 7 gave satisfactory elemental analyses.

[17] ${ }^{1} \mathrm{H}-\mathrm{NMR}\left(300 \mathrm{MHz}, \mathrm{CDCl}_{3}\right): \delta=7.46(\mathrm{~m}, 8 \mathrm{H}), 7.50(\mathrm{~m}, 4 \mathrm{H}), 7.95(\mathrm{~d}, 7.3$ $\mathrm{Hz}, 4 \mathrm{H}$ ). Even at $130^{\circ} \mathrm{C}$ (solvent $\mathrm{CDCl}_{2} \mathrm{CDCl}_{2}$ ) no coalescence is observed in the 'H-NMR spectrum of 7.

\section{Enantio- and Diastereoselective Synthesis of Methyl (2R)-2-Amino-5-oxocarboxylates from Enones and Bislactim-Ether Cuprates**}

\section{By Ulrich Schöllkopf,* Dagmar Pettig, Edda Schulze, Michael Klinge, Ernst Egert,* Bernd Benecke, and Mathias Noltemeyer \\ Dedicated to Professor Heinrich Nöth on the occasion of his 60th birthday}

Lithiated bislactim ethers 2 react with enones to give 1,2- and 1,4-adducts. ${ }^{113}$ In our studies on the asymmetric synthesis of non-proteinogenic amino acids according to the bislactim-ether method ${ }^{[2]}$ we were interested in finding an entry to 1,4-adducts of the type 5 ; we therefore decided to check whether and how the lithium compounds 2 are convertible into cuprates of bislactim ethers. Numerous alkyl and alkenyl cuprates have already been described, ${ }^{[3]}$ whereas very few azaenolate-cuprates have been reported. ${ }^{[4]}$ Heterocyclic azaenolate-cuprates are as yet unknown. After a number of abortive attempts with such $\mathrm{Cu}^{1}$

[*] Prof. Dr. U. Schöllkopf, Dr. D. Pettig, E. Schulze, M. Klinge Institut für Organische Chemie der Universität Tammannstr. 2, D-3400 Göttingen (FRG)

Dr. E. Egert, B. Benecke, M. Noltemeyer Institut für Anorganische Chemie der Universität Tammannstr. 4, D-3400 Göttingen (FRG)

[**] Asymmetric Synthesis via Heterocyclic Intermediates, Part 41._Part 40 : K. Schöllkopf, K.-O. Westphalen, J. Schröder, K. Horn, Liebigs Ann. Chem. 1988, 781. salts, which have already proven useful for the preparation of alkyl and alkenyl cuprates, ${ }^{[3]}$ we found that the bislactim-ether cuprates 3 can be obtained by reaction of 2 with $\mathrm{CuBr} \cdot \mathrm{S}\left(\mathrm{CH}_{3}\right)_{2}$ in the presence of dimethyl sulfide.

The cuprate 3a reacts highly selectively with 2-enones 4 to give 1,4-adducts; the diastereofacial selectivity at the heterocycle is extremely high $(>100: 1$; Table 1$)$, i.e. one obtains almost exclusively the $(2 R, 5 S)$ epimers of the adducts, the precursors of the corresponding $D-\alpha$-amino- $\delta$ oxocarboxylic acids (type 14).<smiles>[R]C1N=C(OC)[C@@H](C(C)C)N=C1OC</smiles>

1

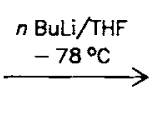<smiles>[R]C1=C(OC)N([Tl])[C@H](C(C)C)C(OC)=N1</smiles>

2

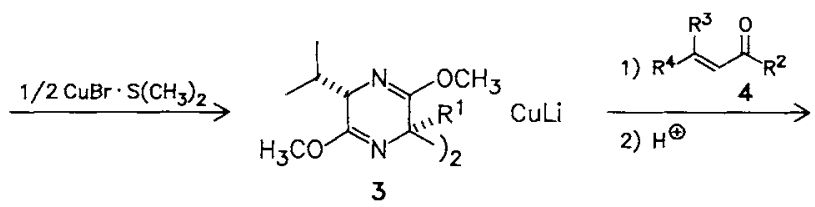<smiles>[R]C(=O)CC([R])([R4])[C@]1([R4])N=C(OC)[C@H](C(C)C)N=C1OC</smiles>

5

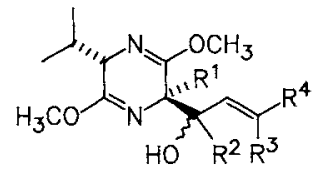

6
$1-3: a, R^{1}=H: b, R^{1}=\mathrm{CH}_{3}$

5, 6: $R^{1}=H$

Table 1. Yields and configurations of the Michael adducts $5, \mathrm{R}^{1}=\mathrm{H}$.

\begin{tabular}{lllllclcr}
\hline 5 & $\mathrm{R}^{2}$ & $\mathrm{R}^{3}$ & $\mathrm{R}^{4}$ & $\begin{array}{c}\text { Yield } \\
{[\%]}\end{array}$ & $\left(2 \mathrm{R}, \mathrm{I}^{\prime} R\right):\left(2 R, 1^{\prime} S\right)[\mathrm{a}][\mathrm{b}]$ & $\mathbf{5}: \mathbf{6}$ \\
\hline a & $-\left(\mathrm{CH}_{2}\right)_{2}-$ & $\mathrm{H}$ & 71 & 100 & $:$ & 2 & $100: \leq 1$ \\
b & $-\left(\mathrm{CH}_{2}\right)_{3}-$ & $\mathrm{H}$ & 71 & 100 & $:$ & 6 & $100: 3$ \\
c & $-\left(\mathrm{CH}_{2}\right)_{4}-$ & $\mathrm{H}$ & 66 & 100 & $:$ & 12 & $100: \leq 1$ \\
d & $-\left(\mathrm{CH}_{2}\right)_{2}-$ & $\mathrm{CH}$ & 52 & 100 & $:$ & 100 & $100: 19$ \\
e & $\mathrm{CH}_{3}$ & $\mathrm{H}$ & $\mathrm{Ph}$ & 62 & 83 & $:$ & 100 & $100: 6$ \\
f & $\mathrm{CH}_{3}$ & $\mathrm{H}$ & 2-Furyl & 60 & 100 & $:$ & 64 & $100: 22$ \\
g & $\mathrm{CH}_{3}$ & $\mathrm{H}$ & $\mathrm{H}$ & 39 & $-[\mathrm{c}]$ & $-[\mathrm{c}]$ & $100: 5$
\end{tabular}

[a] Determined by capillary chromatography and ${ }^{13} \mathrm{C}-\mathrm{NMR}$ spectroscopy. [b] $(2 S)$-epimers $\leq 1$. [c] $(2 R):(2 S)>100: 1$.

Simple cyclic enones such as cyclopentenone and cyclohexenone (4a and $4 \mathbf{b}$, resp.) react also with high enantiofacial selectivity at the double bond. Of four possible diastereomers, almost only the $\left(2 R, 5 S, 1^{\prime} R\right)$-isomers $5 \mathbf{a}$ and $\mathbf{5 b}$ are formed, i.e. two stereocenters are created highly selectively at the same time. The $\left(2 R, 1^{\prime} R\right)$ configuration of $\mathbf{5 b}$ was confirmed by an $X$-ray structure analysis. Cyclic enones with a substituent in the 3-position (e.g. 4d) react with lesser enantiofacial selectivity. The same holds true for conformationally flexible acyclic enones with substituents in the 3-position (e.g. 4e and 4f).$^{[5]}$

Reaction of $3 a$ with $(-)-(R)$-carvone 4 h leads because of favorable double stereoselection (matched case) and because of highly selective protonation at C-2', almost exclusively to $\left(2 R, 1^{\prime} R, 2^{\prime} R\right)-5 h$. The diastereomeric ratio is ca. $100: 3: 2: 1$. The structure of 5 h was confirmed by an $X$ ray analysis. With $(+)-(S)$-carvone (mismatched case) the diastereomers are formed in the ratio $10: 5: 1.5: 1.5$. 